\title{
Arbuscular mycorrhizal fungi associated with the rhizosphere of seedlings and mature trees of Swietenia macrophylla (Magnoliophyta: Meliaceae) in Los Tuxtlas, Veracruz, Mexico
}

Víctor H Rodríguez-Morelos ${ }^{1}$, Alejandra Soto-Estrada ${ }^{2 *}$, Jesús Pérez-Moreno ${ }^{3,4}$, Alicia Franco-Ramírez ${ }^{3}$ and Pablo Díaz-Rivera ${ }^{2}$

\begin{abstract}
Background: Big-leaf mahogany (Swietenia macrophylla King) is the woody species with the highest economic value in Latin America. Currently, it is subject to intensive exploitation, diminishing its natural populations. Due to this decline, the species is a preferred species for reforestation and establishment of commercial tropical plantations. Mycorrhizal symbiosis is a biotic factor scarcely studied in the ecology of this species. Therefore, the objective of this research was to identify the diversity of arbuscular mycorrhizal fungi (AMF) species associated with the rhizosphere of seedlings and mature trees of big-leaf mahogany growing in its natural habitat, a tropical rain forest in Los Tuxtlas, Veracruz, Mexico. Soil samples from a 20-cm depth were taken from the rhizosphere of big-leaf mahogany seedlings and mature trees. Additionally, spores from the rhizosphere soil were propagated on Sorghum vulgare, isolated and identified. The percentage of AMF colonization was also evaluated.

Results: Twenty-three AMF morphospecies belonging to four genera were registered: 11 corresponded to Glomus, 10 to Acaulospora, one to Gigaspora and one to Ambispora. Ambispora gerdemannii, Acaulospora spinosa, A. scrubiculata, A. foveata, Septoglomus constrictum, Claroideoglomus etunicatum, Glomus tenebrosum, Sclerocystis sinuosum, Diversispora aurantium, and Rhizophagus fasciculatus were identified to species level. We report for first time the presence of $G$. tenebrosum and C. etunicatum in natural areas of the humid Mexican tropics. The rhizosphere soil of the trees harbor more morphospecies than soil from seedlings (21 and 11 morphospecies, respectively). Sorghum plants inoculated with rhizosphere soil from big-leaf trees showed higher percentages of total mycorrhizal colonization, arbuscules and hyphae $(P<0.01)$ compared with plants inoculated with rhizosphere soil from seedlings.

Conclusions: Twenty-three AMF morphospecies included in the genera Glomus, Acaulospora, Gigaspora and Ambispora were found associated with rhizosphere soil of mahogany trees growing in its natural habitat. The diversity of AMF genera and species found was around two times greater in mature trees than in seedlings. Some AMF species were only detected when trap-plants culture methods were employed, stressing the importance of this technique. This information has great potential for biotechnological application when performing reintroductions or reforestation with the tropical tree mahogany.
\end{abstract}

Keywords: Arbuscular mycorrhizae; Morphospecies; Seedlings; Spores; Tropical trees

\footnotetext{
*Correspondence: alejandras@colpos.mx

${ }^{2}$ Colegio de Postgraduados, Campus Veracruz. Km. 88.5 Carretera Federal

Xalapa-Veracruz, Tepetates, Veracruz C.P. 91690, México

Full list of author information is available at the end of the article
} 


\section{Background}

The bigleaf mahogany (Swietenia macrophylla King) is the timber species of greatest economic value in Latin America and is currently the main source of genuine mahogany on the wood market (OIMT 2004). Its natural distribution includes fragmented populations from southeastern Mexico along the Atlantic coast of Central America and northern South America, occupying a large geographical arc south of the Amazon, between Brazil, Colombia, Peru and Bolivia (Lamb 1966; Snook 1996). Mahogany is a tropical species that demands much light for growth (Mayhew and Newton 1998); therefore, its natural regeneration is associated with significant disturbance to sites produced by fires or hurricanes (Snook 1996). This forest tree species is subjected to intense levels of exploitation and international trade, showing therefore a decline in its population size and increased population fragmentation in several areas of its natural distribution (Navarro and Hernández 2004; OIMT 2004). In Mexico, over the past three decades, a loss of $76 \%$ of the tropical evergreen forest areas containing mahogany trees has been reported (Calvo et al. 2000). Currently, mahogany is a preferred species for reforestation and establishment of commercial plantations in the tropics.

Even though it has a great potential for practical application, one of the poorly studied biotic factors of this species is its relationship with arbuscular mycorrhizal fungi (AMF), especially in their natural distribution areas. Different studies indicate a clear colonization of vesicles and arbuscules in the secondary roots of seedling and mahogany trees in natural areas (Herrera and Ferrer 1980), in young plantations (Noldt and Bauch 2001) and agroforestry systems and tropical forests of Southeast Asia where mahogany has been introduced for cultivation (Dhar and Mridha 2006; Shi et al. 2006; Mridha and Dhar 2007). However, in general terms, the identity of AMF associated with mahogany in natural areas, has received little attention. It is known that most tropical forest species are associated with AMF and have a wide range of dependence on them, depending on successional stages and soil fertility (Janos 1980a; Le Tacon et al. 1987). Also, it has been shown that pioneer plant species in tropical areas are more dependent on AMF, in soils poor in minerals, than climax plant species (Zangaro et al. 2000). Recently, studies on arbuscular mycorrhiza have increased due to the little knowledge we have regarding the diversity and potential of AMF in association with tropical plants. Studies related to the production of mycorrhizal inoculum for the production of tropical plant species are emerging; consequently, despite its paramount importance, currently there is only a limited use of these inocula in reforestation programs on a large scale (RamosZapata and Guadarrama 2004). In Mexico, there is little knowledge of AMF richness and its role in the ecological processes of tropical land areas that influence the development of plants with which they are associated (GuadarramaChávez et al. 2007). Most research on AMF in Mexico has been developed in agricultural areas and in many cases, has focused on determining plant responses to symbiosis, regardless of the origin or identity of the AMF (Varela and Trejo 2001). However, it is important to note that the current perspective is that the AMF communities differentially influence the growth and establishment of tree seedlings in tropical ecosystems, influencing the composition of plant communities (Kiers et al. 2000; Husband et al. 2002). In this context, the objective of the present investigation was to identify the species of AMF associated with the rhizosphere of seedlings and mature mahogany trees in a fragment of tropical rainforest of Los Tuxtlas, Veracruz, Mexico. We also evaluated the mycorrhizal inoculum potential of rhizosphere soil from such seedlings and mahogany trees.

\section{Methods \\ Study site}

The sampling area was a fragment of tropical rainforest with seedlings and trees of S. macrophylla established naturally. The study area is located in the town of Maxacapan, municipality of Catemaco, within the region of Los Tuxtlas, Veracruz, Mexico ( $18^{\circ} 23^{\prime} \mathrm{N}, 95^{\circ} 07^{\prime} \mathrm{W}$; average elevation of $385 \mathrm{masl}$ ). The soil is an ultisol with a light brown color, a sandy-loamy texture and abundant organic matter in the first 10 to $15 \mathrm{~cm}$ of soil depth. The vegetation area is disturbed from its original composition due to selective timber harvesting, and is generally surrounded by pastures and coffee plantations.

The climate is warm-humid with an average annual temperature of $27^{\circ} \mathrm{C}$ (Pérez-Rojas et al. 2000). The average annual rainfall in the region is $4,964 \mathrm{~mm}$ with a marked dry season from March to May (Soto and Gama 1997), rain during the summer and abundant rain in autumn (Pérez-Rojas et al. 2000). The Los Tuxtlas region represents the northern limit of the distribution of tropical rainforest in the Americas and the last relic of this type of vegetation in the state of Veracruz (Dirzo and Miranda 1991). The vegetation of the tropical rain forest in the region has lost $84 \%$ of its original cover due to human activity causing a high degree of fragmentation (Dirzo and Mc 1992).

\section{Collection of rhizosphere soil and establishment of trap-plants}

Sampling was conducted in June 2008 and consisted of collecting rhizosphere soil surrounding five seedlings and five mature trees of $S$. macrophylla. The seedlings had an average basal diameter $( \pm \mathrm{SD})$ of $4.5 \pm 1.5 \mathrm{~cm}$ and a mean height $( \pm \mathrm{SD})$ of $35.6 \pm 8.5 \mathrm{~cm}$, while trees had an average basal diameter $( \pm \mathrm{SD})$ of $1.2 \pm 0.5 \mathrm{~m}$ and an average height 
$( \pm$ SD) of $19.5 \pm 4.5 \mathrm{~m}$. To collect soil, organic matter was first removed from around the plants and a shovel was used to remove the roots of mahogany trees and to collect about two $\mathrm{kg}$ of rhizosphere soil from each seedling or tree. Soil samples were placed directly into plastic bags, which were placed in coolers for transport to the Laboratory at the Colegio de Postgraduados and stored at $6^{\circ} \mathrm{C}$ during two months before analysis.

In order to detect additional AMF species to those found at the time of soil collection, which could only be expressed in soil samples as somatic phases, and to determine the mycorrhizal inoculum potential, a trap-plant method was applied using sorghum (Sorghum vulgare L.). This species was used because of its high germination percentage, early susceptibility to mycorrhizal colonization and abundant root production. It is important to note that the establishment of trap-plants allows: i) to corroborate the identification of species based on spores obtained in the field, which are often damaged, causing difficulty in accurate identification, and ii) to obtain sporulation of species that do not sporulate under natural conditions (Guadarrama et al. 2014). The methodology first involved the sterilization of the loamy-sandy soil (that was poor in phosphorus) with water vapor at $100^{\circ} \mathrm{C}$ for eight hours in an autoclave. The soil was then placed in $2 \mathrm{~L}$ pots, filling them to $75 \%$ capacity. On top of this soil was placed a uniform layer of $250 \mathrm{~g}$ of rhizosphere soil, resulting in a total of 10 pots corresponding to the number of samples. In each pot, a uniform layer of sorghum seed was sown, watered and maintained under a shade mesh for six months at an average temperature and relative humidity of $26^{\circ} \mathrm{C}$ and $80 \%$, respectively. During this time, frequent irrigation with tap water was performed depending on the needs of the plants. In addition, during the last three months, all potted plants were watered every 15 days with $200 \mathrm{ml}$ of Long Ashton nutrient solution modified by Hewitt (1966). After six months, the irrigations were suspended and the plants were cut from the stem base to favor spore production, following the methods described by Carreón-Abud et al. (2013); Hernández-Cuevas and García-Sánchez (2008).

\section{Identification of AMF species}

The extraction and counting of spores were carried out using $100 \mathrm{~g}$ of rhizosphere soil collected from both, the field and trap-plants and the method of wet sieving and decanting established by Gerdemann and Nicolson (1963). Spores were extracted and separated into morphotypes by color, shape and size. Subsequently, permanent preparations were made with alcohol and polyvinyl-glycerol (PVLG) and PVLG with Melzer's solution according to Schenck and Pérez (1990). The isolated spores were measured under a phase contrast microscope. Characteristics such as number of spore layers, ornamentation of outer layers, shape and type of hyphal attachments and sporogenous cells, and the wall layer reactions to Melzer's reagent were also recorded. Species identification was made according to species descriptions provided by the International Culture Collection of Vesicular Arbuscular Mycorrhizal Fungi (INVAM 2014) following the classification of Redecker et al. (2013).

\section{Determination of mycorhizal colonization}

After six months of establishment, the sorghum trap-plants were harvested and the roots were examined to determine the formation of AMF structures, quantify the colonization percentage, and estimate the mycorrhizal inoculum potential for the rhizosphere soil of seedlings and mature trees. Evaluation of root mycorrhizal colonization was performed by clearing and staining the roots (Phillips and Hayman 1970), and quantifying colonization according to McGonigle et al. (1990) by determining the percentage of arbuscules, vesicles and hyphae in the roots of sorghum. Additionally, the percentage of endophytic fungi was determined in the sorghum roots.

\section{Statistical analysis}

For the number of spores from the field soil and colonization variables, ANOVA analyses were performed using a linear mixed effects model, considering the state of mahogany development (seedlings and adults) as fixed effects and the individual specimens as a random effect nested in developmental stage, with three replicates per specimen. Subsequently, the test for differences among means (pdiff, $\mathrm{P}<0.05$ ) using the t-statistic was applied. The analysis was performed using the GLM procedure in SAS (SAS Institute Inc 2009). The statistical model used was:

$$
\begin{aligned}
& Y_{i j k}=\mu+\mathrm{ED}_{i}+\mathrm{Id}_{(\mathrm{ED}) j(i)}+\varepsilon_{i j k} \\
& \varepsilon_{i j k} \approx \mathrm{NII},\left(0, \sigma_{\varepsilon}^{2}\right)
\end{aligned}
$$

where: $\mathrm{Y}_{\mathrm{ijk}}=$ response variable, $\mathrm{ED}_{\mathrm{i}}=\mathrm{i}^{\mathrm{th}}$ stage of development, Id $(E D) j(i)=j^{\text {th }}$ individual nested in the $i^{\text {th }}$ stage of development, and $€_{\mathrm{ijk}}=$ residual error. The percentages of mycorrhizal colonization and colonization of endophytic fungi were transformed to square-roots to meet the assumptions of normality for ANOVA.

\section{Results}

\section{Identification of AMF species}

A total of 23 morphotypes of AMF corresponding to three orders and four families were recorded from the rhizosphere of mahogany seedlings and trees (Table 1). Ten of these morphotypes were identified to species level. From the 23 morphotypes, a total of 11 species belong to the genus Glomus, 10 to the genus Acaulospora, and one each to the genera Gigaspora and Ambispora. In the rhizosphere soil of seedlings, 11 morphotypes were 
registered corresponding to the genera Glomus and Acaulospora; while from the soil rhizosphere of trees, 21 morphotypes were recorded from four genera (Glomus, Acaulospora, Gigaspora and Ambispora). Nine morphotypes (A. scrobiculata, A. spinosa, Acaulospora sp. 2, Acaulospora sp. 5, Acaulospora sp. 6, D. aurantium, C. etunicatum, R. fasciculatus and Glomus sp. 3) were common in both plant stages. In contrast, A. gerdemannii, S. constrictum, S. sinuosum, G. tenebrosum, Glomus sp. 1, Glomus sp. 2, Glomus sp. 5, and Gigaspora sp. were found exclusively in the rhizosphere of mature trees. The morphospecies Acaulospora sp. 4 and Acaulospora sp. 7 were recorded specifically associated with seedlings. There was a greater diversity of genera and species of AMF associated with trees compared to seedlings. The percentage incidence in trees and seedlings and their morphological characteristics are shown in Figures 1 and 2, respectively.

\section{Colonization and spore abundance}

The variables evaluated for sorghum showed significant differences in relation to the type of rhizosphere soil used as a source of inoculum (Table 2). The rhizosphere soil from $S$. macrophylla trees originated more spores $(152.80 \pm 3.2$ SEM) than that from seedlings $(87.3 \pm 3.2$ SEM) $(\mathrm{P}<0.01)$. Similarly, the number of spores was higher $(\mathrm{P}<0.01)$ from trap-plants with rhizosphere soil from trees $(295 \pm 4.4 \mathrm{SEM})$ than with rhizosphere soil from seedlings (132.3 \pm 4.4 SEM) (Table 2). Sorghum plants inoculated with tree soil had higher percentages of total mycorrhizal colonization, arbuscules and hyphae $(53.3 \pm 2.0$ SEM, $26.3 \pm 1.9$ SEM and $26.5 \pm 1.4$ SEM, respectively), compared with that inoculated with seedling soil $(\mathrm{P}<0.01)$. Percent colonization by vesicles $(11.3 \pm$ 1.0 SEM) and by endophytic fungi $(6.1 \pm 0.9 \mathrm{SEM}) \mathrm{did}$ not differ significantly $(\mathrm{P}>0.05)$. The use of sorghum as a trap-plant increased the number of spores by $93 \%$ and

Table 1 Morphospecies of arbuscular mycorrhizal fungi associated with the rhizosphere of seedlings and adult trees of mahogany in a tropical rainforest in Los Tuxtlas, Veracruz, Mexico

\begin{tabular}{|c|c|c|}
\hline \multirow[t]{2}{*}{ Order/family } & \multicolumn{2}{|c|}{ Species of AMF Associated with } \\
\hline & Seedlings & Trees \\
\hline Ambisporaceae & & Ambispora gerdemannii * \\
\hline Diversisporaceae & Diversispora aurantium & Diversispora aurantium \\
\hline \multirow[t]{9}{*}{ Acaulosporaceae } & Acaulospora spinosa & Acaulospora spinosa \\
\hline & Acaulospora scrobiculata & Acaulospora scrobiculata \\
\hline & & Acaulospora foveata \\
\hline & & Acaulospora sp. 1 \\
\hline & Acaulospora sp. 2 & Acaulospora sp. 2 \\
\hline & Acaulospora sp. 4 & Acaulospora sp. 3 \\
\hline & Acaulospora sp. 5 & Acaulospora sp. 5 \\
\hline & Acaulospora sp. 6 & Acaulospora sp. 6 \\
\hline & Acaulospora sp. 7 & \\
\hline Gigasporaceae & & Gigaspora sp.* \\
\hline Glomerales & Claroideoglomus etunicatum & Claroideoglomus etunicatum \\
\hline \multicolumn{3}{|c|}{ Claroideoglomeraceae } \\
\hline \multirow[t]{9}{*}{ Glomeraceae } & & Sclerocystis sinuosum ** \\
\hline & & Rhizophagus fasciculatus \\
\hline & & Glomus tenebrosum \\
\hline & & Septoglomus constrictum \\
\hline & & Glomus sp.1 \\
\hline & & Glomus sp. $2^{* *}$ \\
\hline & Glomus sp.3 & Glomus sp.3 \\
\hline & & Glomus sp.4 \\
\hline & & Glomus sp.5 \\
\hline
\end{tabular}

* Detected only in trap-plant cultures. ${ }^{* *}$ Detected only in natural soil. Remaining morphotypes were detected in both trap-plant cultures and natural soil. Species nomenclature follows Redecker et al. (2013). 

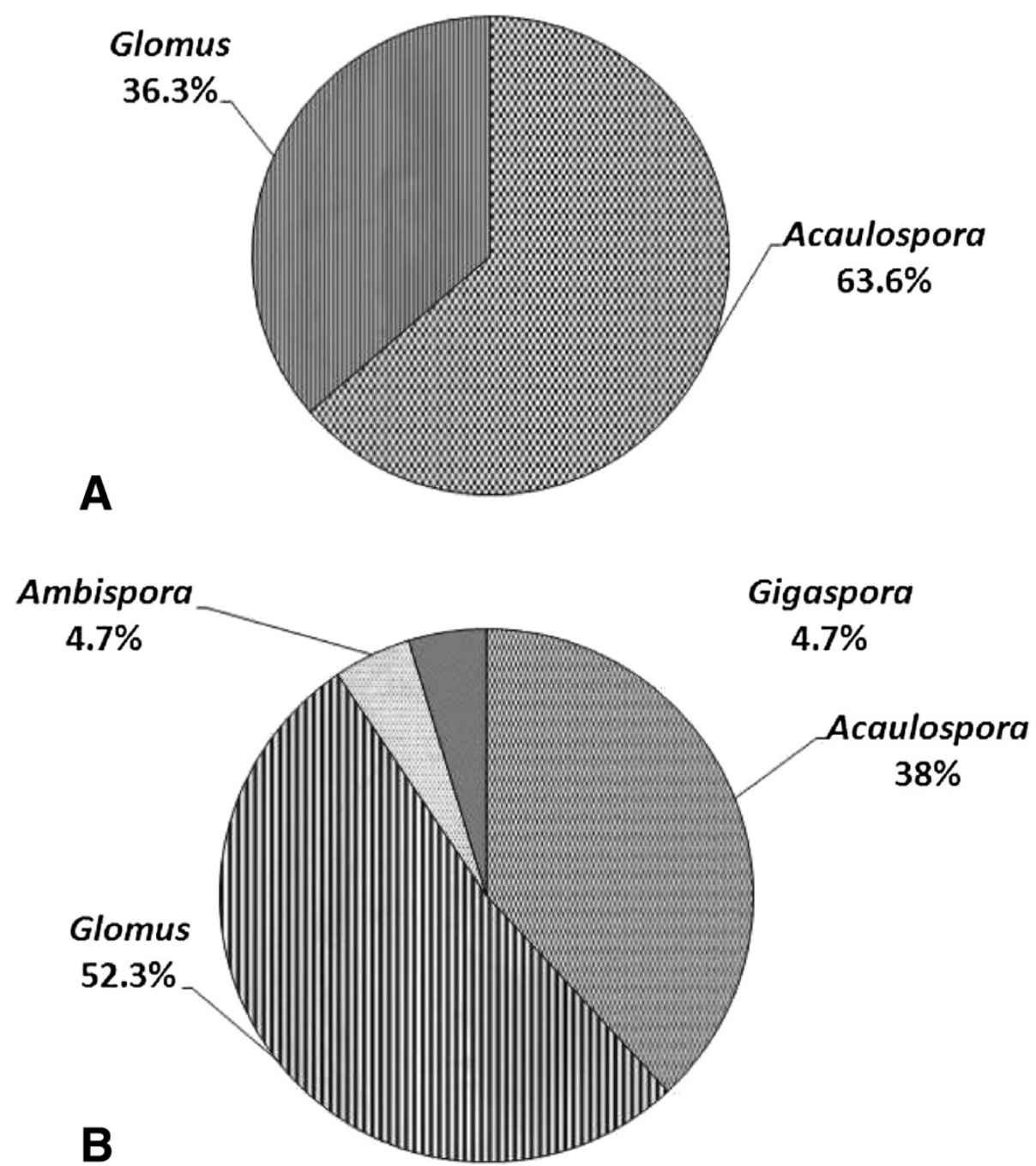

Figure 1 Percentage distribution of the arbuscular mycorrhizal fungi genera associated with the rhizosphere of seedlings (A) and mature trees (B) of Swietenia macrophylla in a tropical rainforest in Los Tuxtlas, Veracruz, Mexico.

$51 \%$ compared to soil collected in the field from mahogany trees and seedlings, respectively.

\section{Discussion}

AMF morphotypes found in the rhizosphere from both seedlings and mature trees of S. macrophylla were identified as primarily belonging to the genera Glomus and Acaulospora. Additionally, in the case of mature trees species were identified as belonging to the genera Ambispora and Gigaspora. These results differ from those of Dhar and Mridha (2006) who found species from the genera Glomus and Gigaspora, but also species belonging to Scutellospora and Entrophospora in the rhizosphere of mahogany trees in a natural forest in Bangladesh. Meanwhile, Mridha and Dhar (2007) found that in mahogany trees in agroforestry systems established in Bangladesh, members of the genus Glomus were the dominant taxonomic group and only a small proportion of species corresponded to the genera Acaulospora and Scutellospora. The results also contrast with those of Shi et al. (2006) who reported that Glomus was the dominant genus in the rhizosphere of 14 genera of Meliaceae (including 2 species of Sweitenia) in a tropical forest in China, and to a lesser extent the genera Acaulospora, Gigaspora, Scutellospora and Entrophospora. These differences in AMF community composition could be linked to geographic environmental variations or the plant genotypes involved.

The AMF species found in this study have been reported to be associated with a variety of hosts and diverse vegetation types in Mexico, such as tropical rainforest (Varela-Fregoso et al. 2008; Guadarrama and Álvarez-Sánchez 1999), tropical dry forest (Gavito et al. 2008), deciduous tropical dry forest (Guadarrama-Chávez et al. 2007; Allen et al. 1998), mountain cloud forest 


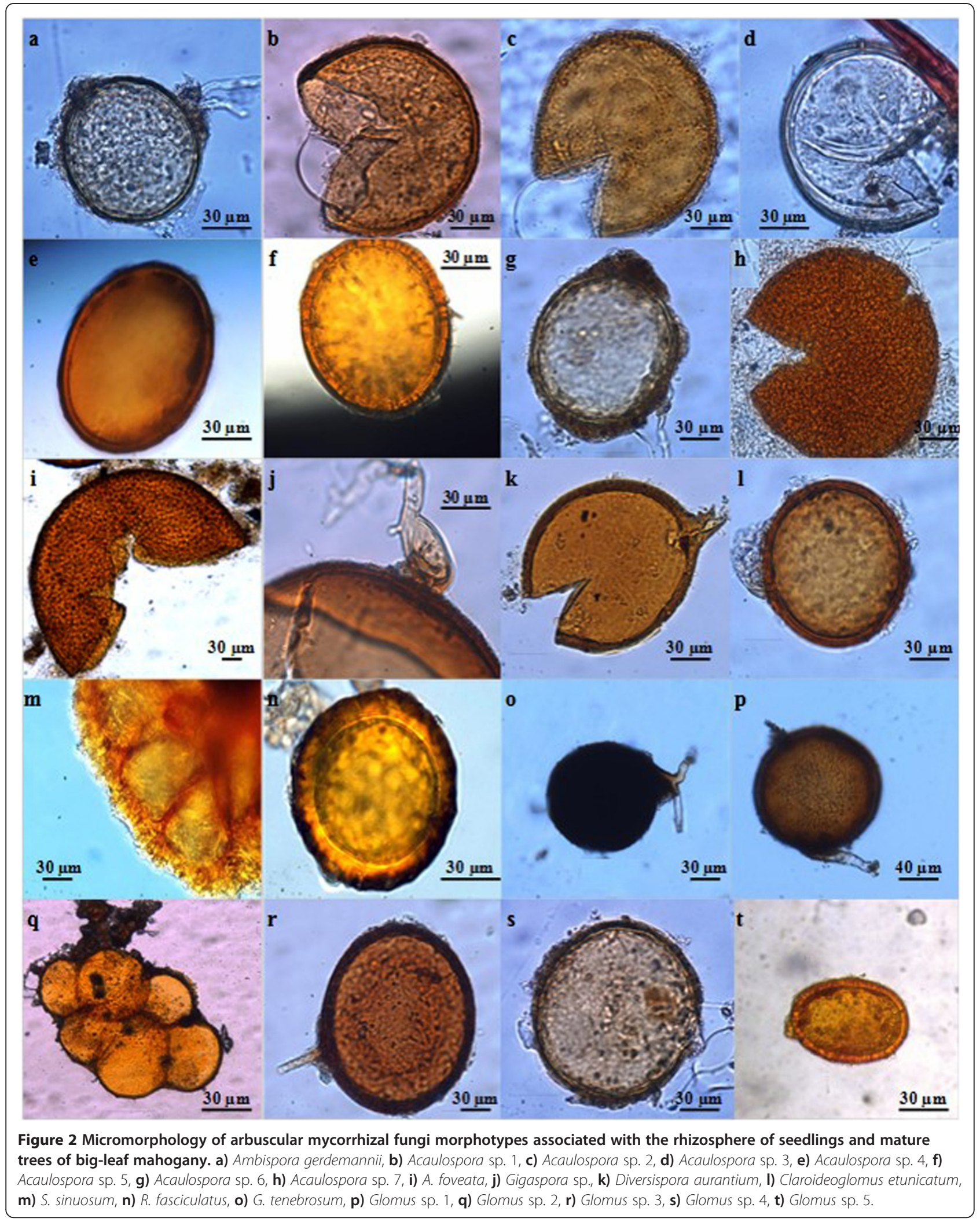


Table 2 Mycorrhizal structures on sorghum plants inoculated with rhizosphere soil from seedlings and mature mahogany trees

\begin{tabular}{lcccc}
\hline & \multicolumn{2}{c}{ Original values } & \multicolumn{2}{c}{ Transformed values } \\
\hline Variables\development stage & Trees & Seedlings & Trees & Seedlings \\
Spore number in sorghum & $295.0 \pm 4.40 \mathrm{a}$ & $132.3 \pm 4.39 \mathrm{~b}$ & & \\
Total colonization & $53.3 \pm 2.01 \mathrm{a}$ & $41.5 \pm 2.01 \mathrm{~b}$ & $51.4 \pm 0.03 \mathrm{a}$ & $40.6 \pm 0.03 \mathrm{~b}$ \\
$\%$ Arbuscules & $26.3 \pm 1.88 \mathrm{a}$ & $17.6 \pm 1.88 \mathrm{~b}$ & $24.6 \pm 0.06 \mathrm{a}$ & $14.1 \pm 0.06 \mathrm{~b}$ \\
\% Vesicles & $11.3 \pm 1.01 \mathrm{a}$ & $13.23 \pm 1.01 \mathrm{a}$ & $10.6 \pm 0.02 \mathrm{a}$ & $11.8 \pm 0.02 \mathrm{a}$ \\
$\%$ Hyphae & $26.5 \pm 1.40 \mathrm{a}$ & $14.6 \pm 1.40 \mathrm{~b}$ & $22.6 \pm 0.02 \mathrm{a}$ & $14.21 \pm 0.02 \mathrm{~b}$ \\
\% Endophytes & $6.09 \pm 0.93 \mathrm{a}$ & $5.5 \pm 0.93 \mathrm{a}$ & $5.2 \pm 0.05 \mathrm{a}$ & $4.12 \pm 0.05 \mathrm{a}$ \\
Spore number in natural soil & $152.8 \pm 3.23 \mathrm{a}$ & $87.3 \pm 3.23 \mathrm{~b}$ & & \\
\hline
\end{tabular}

Within rows, different letters indicate significant differences $(P<0.01)$. Values are means \pm standard error of the mean.

(Violi et al. 2008) and grassland (Franco-Ramírez et al. 2007; Ramírez-Gerardo et al. 1997). Also, the species reported in this paper have been found in Mexico associated with various crops such as maize (Guadarrama-Chávez et al. 2007), sugarcane, coffee and bananas (Varela and Trejo 2001). This demonstrates, in general, enormous ecological flexibility and lack of specificity of AMF, although it has also been shown a significant functional variability among fungal species belonging to this group. The AMF species composition thus could alter plant community structure (Smith and Read 2008; Klironomos 2000).

The average number of spores recorded from trees in this study is similar to that found by Mridha and Dhar (2007) in agroforestry systems (141 spores/100 g of soil), but lower than that reported by Dhar and Mridha (2006) and Shi et al. (2006) for mahogany trees in tropical forests of Southeast Asia (440 and 346 spores/100 g of soil, respectively). The number of spores produced in inoculated sorghum plants was higher than that found in the soil collected from the rhizosphere of trees (93.0\% higher) and seedlings (51.0\% higher) in the field. This difference could be explained by the fact that there are AMF species present exclusively as somatic propagules in the field that could only be detected by the trap-plant method (Guadarrama et al. 2014).

Husband et al. (2002) found that the age of the host can determine the composition of AMF populations in tropical ecosystems. By using molecular techniques in the extraction of fungal DNA from the colonized roots of Tetragastris panamensis (Engl.) Kuntse, these authors observed that when the age of seedlings of tropical trees increases the diversity of AMF declines. Similarly, Kumar et al. (2009) found higher colonization percentages and densities of AMF spores in young plants compared with old trees of maidenhair (Ginkgo biloba L.). Our results showed the opposite trend, finding more AMF species in the rhizosphere of mature trees than in seedlings, which can be explained by the fact that when trees have been longer periods of time in natural ecosystems, the possibility to be colonized by a more diverse community of AMF propagules can be increased. Similarly, than in our case Wubet et al. (2009) also found AMF species associated with both mature tropical trees and seedlings, while other species were unique to only one of the two age categories.

The production of AMF spores in tropical forests varies according to climatic seasonality during the year (Allen et al. 1998; Guadarrama and Álvarez-Sánchez 1999; Picone 2000; Lovelock et al. 2003; Ramos-Zapata et al. 2006; Vargas et al. 2010). Recently, Guadarrama et al. (2014) demonstrated that seasonality has a strong influence on AMF diversity in subtropical dry forests. Therefore, the additional use of trap-plants allows the evaluation of the mycorrhizal inoculum potential of soil (Guadarrama et al. 2014), thus being useful in the identification of AMF species that do not produce spores during the period in which samples are collected from the field (Stürmer 2004). In our study, Ambispora gerdemannii and Gigaspora sp. were not found in the natural soil collected, but they were recorded when trap-plant cultures were used. However, it is important to consider that trap-plant cultures do not necessarily show the whole composition of AMF communities, because the species used as host plants can affect sporulation of AMF communities (Bever et al. 1996). For example, species such as G. sinuosum and G. clavisporum do not produce spores when using the trap-plant Sorghum vulgare (Guadarrama-Chávez et al. 2007). Our results therefore suggest that in order to have a more complete picture of the AMF communities associated with tropical trees, it is important to use both methodologies, collection of AMF from rizosphere soil and cultivation using trapplants. Dhar and Mridha (2012) showed colonization percentages for hyphae and vesicles of 60 and 40\%, respectively, and the percentage of arbuscules of $19 \%$ for mahogany plantations in Bangladesh. A lower potential 
for mycorrhizal colonization of rhizosphere soil from seedlings in comparison to mature trees (expressed as lower percentage of total mycorrhizal colonization, arbuscules and AMF hyphae) was recorded in the present work.

In natural ecosystems, a great diversity of AMF colonize plants simultaneously (Vandenkoornhuyse et al. 2002), but generally have little taxonomic specificity to associate with plant roots (Smith and Read 2008). However, it is important to consider that tree species from tropical forests exhibit differential responses and compatibility in growth in relation to AMF species (Pouyu-Rojas et al. 2006) and AMF soil communities (Fischer et al. 1994; Kiers et al. 2000; Allen et al. 2003; 2005). Other evidence indicates that tree identity and the composition of the plant community determine the composition of AMF in tropical ecosystems (Lovelock et al. 2003; Lovelock and Ewel 2005).

Anthropogenic disturbances such as loss of vegetation through land use change can reduce AMF diversity in tropical (Cuenca et al. 1998) and subtropical (Guadarrama et al. 2014) ecosystems, and also affect its composition (Gavito et al. 2008). In this regard, several studies have shown that the genera Gigaspora and Scutellospora are more susceptible to disturbances in plant communities (Guadarrama-Chávez et al. 2007; Lovera and Cuenca 2007). The loss of biodiversity in the soil is a little-studied topic that requires more attention because AMF species can influence the diversity and productivity of plant communities in natural ecosystems (van der Heijden et al. 1998). The need for using native AMF in restoration activities in degraded tropical areas because of its potential for adapting to the environmental conditions of a particular site has been previously emphasized (Allen et al. 2005; Cuenca et al. 2007; Guadarrama-Chávez et al. 2007).

Our results confirm the high diversity of AMF associated with the rhizosphere of S. macrophylla, similar to that reported in previous studies in Los Tuxtlas, Mexico. Varela-Fregoso et al. (2008) cataloged the species of this tropical region and recorded 60 AMF species. There is a relationship between the number and composition of species in the rhizosphere soil and the stage of development of $S$. macrophylla. In tropical ecosystems there is a great diversity of AMF, but studies of AMF in these ecosystems are scarce compared to temperate ecosystems or agroecosystems; additionally the characteristics of AMF found in tropical zones do not fit species previously described in the literature (Lovera and Cuenca 2007). Positive results in terms of growth have been reported by Huante et al. (2012) in a species similar to mahogany, Swietenia humilis, following inoculation with AMF. Knowledge of the structure and function of AMF communities is an important factor to be considered in the management of this biotic resource so that it can be integrated into future environmental restoration activities, especially in degraded tropical regions where the availability of nutrients such as phosphorus is a limiting factor in plant growth. Thus, AMF is a key factor in the growth and survival of plants in early successional stages of plant communities (Janos 1980b, 1996; Cuenca et al. 1998). Therefore, knowing the diversity of AMF associated with different growth stages of plant species is vital for maintaining the diversity and sustainability of tropical ecosystems.

\section{Conclusions}

In this research, 23 AMF morphospecies belonging to the genera Glomus, Acaulospora, Gigaspora and Ambispora were found associated with rhizosphere soil of mahogany trees growing in its natural habitat. The diversity of AMF genera and species found was around two times greater in mature trees than in seedlings. Some AMF species were only detected when trap-plants culture methods were employed, stressing the importance of this technique. This information has great potential for application and should be considered when performing reintroductions or reforestation with the native tropical mahogany tree.

\section{Competing interests}

The authors of this paper declare that we have no competing interests.

\section{Authors' contributions}

VHRM co-designed the study, collected and analyzed data, and drafted the manuscript. ASE co-designed the study, co-directed the research, and revised manuscript. JPM co-directed the research, and revised the manuscript. AFR identified all the arbuscular mycorrhizal fungi species reported en this paper. PDR contributed in the experimental design and the analysis of data. All authors read and approved the final manuscript.

\section{Authors' information}

VHRM, Instituto Nacional de Investigaciones Forestales Agrícolas y Pecuarias, Campo Experimental Las Huastecas. Km. 55 Carretera Federal TampicoMante, Villa Cuauhtémoc, Tamaulipas, México. C.P. 89610. ASE, Colegio de Postgraduados, Campus Veracruz. Km. 88.5 Carretera Federal Xalapa-Veracruz, Tepetates, Veracruz, México. C.P. 91690. JPM, Colegio de Postgraduados, Microbiología-Edafología, Campus Montecillo. Km. 36.5 Carretera-Federa México-Texcoco, Montecillo, Estado de México, México. C.P. 56230 Animal and Plant Science Department, University of Sheffield, Sheffield S10 2TN, England, UK. AFR, Colegio de Postgraduados, Microbiología-Edafología, Campus Montecillo. Km. 36.5 Carretera-Federal México-Texcoco, Montecillo, Estado de México, México. C.P. 56230. PDR, Colegio de Postgraduados, Campus Veracruz. Km. 88.5 Carretera Federal Xalapa-Veracruz, Tepetates, Veracruz, México. C.P. 91690.

\section{Acknowledgements}

We thank Sir David J. Read, Animal and Plant Sciences Department, University of Sheffield, England, UK, for his critical observations, which improved the manuscript.

\section{Author details}

${ }^{1}$ Instituto Nacional de Investigaciones Forestales Agrícolas y Pecuarias, Campo Experimental Las Huastecas. Km. 55 Carretera Federal Tampico-Mante, Tamaulipas, Villa Cuauhtémoc C.P. 89610, México. ${ }^{2}$ Colegio de Postgraduados, Campus Veracruz. Km. 88.5 Carretera Federal Xalapa-Veracruz, Tepetates, Veracruz C.P. 91690, México. ${ }^{3}$ Colegio de Postgraduados, Microbiología-Edafología, Campus Montecillo. Km. 36.5 Carretera-Federal México-Texcoco, Montecillo, Estado de México C.P. 56230, México. ${ }^{4}$ Animal and Plant Science Department, University of Sheffield, Sheffield S10 2TN, England, UK.

Received: 12 April 2014 Accepted: 23 June 2014

Published online: 01 August 2014 


\section{References}

Allen EB, Rincón E, Allen MF, Pérez-Jiménez A, Huante P (1998) Disturbance and seasonal dynamics of mycorrhizae in a tropical deciduous forest in Mexico. Biotropica 30:261-274

Allen EB, Allen MF, Egerton-Warburton L, Corkidi L, Gómez-Pompa A (2003) Impacts of early-and late-seral mycorrhizae during restoration in seasonal tropical forest, México. Ecol Appl 13:1701-1717

Allen MF, Allen EB, Gómez-Pompa A (2005) Effects of Mycorrhizae and Nontarget Organisms on Restoration of a Seasonal Tropical Forest in Quintana Roo, Mexico: Factors Limiting Tree Establishment. Restauration Ecol 13:325-333

Bever JD, Morton JB, Antobovics J, Schultz P (1996) Host dependent sporulation and species diversity of arbuscular mycorrhizal fungi in a mown grassland. J Ecol 84:71-82

Calvo J, Bolaños R, Watson V, Jiménez H (2000) Diagnóstico de la caoba (Swietenia macrophylla King) en Mesoamérica: Visión general (Evaluation of Mahogany in Mesoamerica: General Overview). Tropical Science Center / PROARCA / CAPAS, San José, Costa Rica

Carreón-Abud Y, Jerónimo-Treviño E, Beltrán-Nambo MA, Martínez-Trujillo M, Trejo-Aguilar D, Gavito ME (2013) Aislamiento y propagación de cultivos puros de hongos micorrízicos arbusculares provenientes de huertas de aguacate con diferente manejo agrícola por la técnica de minirizotrón. Revista Mexicana Micología 37:29-39

Cuenca G, Cáceres A, Oirdobro G, Hasmy Z, Urdaneta C (2007) Las micorrizas arbusculares como alternativa para una agricultura sustentable en áreas tropicales. Interciencia 32:23-29

Cuenca G, De Andrade Z, Escalante G (1998) Diversity of Glomalean spores from natural, disturbed and revegetated communities growing on nutrient-poor tropical soils. Soil Biol Biochem 30:711-719

Dhar PP, Mridha M (2006) Biodiversity of arbuscular mycorrhizal fungi in different trees of madhupur forest, Bangladesh. J For Res 17:201-205

Dhar PP, Mridha M (2012) Arbuscular mycorrhizal associations in different forest tree species of Hazarikhil forest of Chittagong, Bangladesh. J For Res 23:115-122

Dirzo R, Miranda A (1991) El limite boreal de la selva tropical húmeda en el continente americano: contracción de la vegetación y solución de una controversia. Interciencia 16:240-247

Dirzo R, Mc G (1992) Rates of deforestation in Los Tuxtlas a neotropical area in south east Mexico. Conserv Biol 6:84-90

Fischer CR, Janos DP, Perry DA, Linderman RG, Sollins P (1994) Mycorrhiza inoculums potentials in tropical secondary succession. Biotropica 26:369-377

Franco-Ramírez A, Ferrera-Cerrato R, Varela-Fregoso L, Pérez-Moreno J, Alarcón A (2007) Arbuscular mycorrhizal fungi in chronically petroleum contaminated soils in Mexico and the effects of petroleum hydrocarbons on spore germination. J Basic Microbiol 47:378-383

Gavito ME, Pérez-Castillo D, González-Monterrubio CF, Vieyra-Hernández T, Martínez-Trujillo M (2008) High compatibility between arbuscular mycorrhizal fungal communities and seedlings of different land use types in a tropical dry ecosystem. Mycorrhiza 19:47-60

Gerdemann JW, Nicolson TH (1963) Spores of mycorrhizal Endogone species extrated from soil by wet sieving and decanting. Transations Br Mycol Soc 46:235-244

Guadarrama P, Álvarez-Sánchez FJ (1999) Abundance of arbuscular mycorrhizal fungi spores in different environments in a tropical rain forest, Veracruz, Mexico. Mycorrhiza 8:267-270

Guadarrama-Chávez P, Camargo-Ricalde SL, Hernández-Cuevas L, Castillo-Argüero S (2007) Los hongos micorrizógenos arbusculares de la región de Nizanda, Oaxaca, México. Bol Soc Bot Méx 81:131-137

Guadarrama P, Castillo S, Ramos-Zapata JA, Hernández-Cuevas LV, CamargoRicalde SL (2014) Arbuscular mycorrhizal fungal communities in changing environments: The effects of seasonality and anthropogenic disturbance in a seasonal dry forest. Pedobiologia 57:87-95

Hernández-Cuevas LV, García-Sánchez R (2008) Propagación por esporas: el caso de las micorrizas arbusculares. In: Álvarez-Sánchez J, Monroy-Ata A (ed) Técnicas de estudio de las asociaciones micorrízicas y sus implicaciones en la restauración: 29-42. Universidad Nacional Autónoma de México, México, D.F

Herrera RA, Ferrer RL (1980) Vesicular-arbuscular Mycorrhiza in Cuba. In: Mikola P (ed) Tropical Mycorrhizae Research: 156-162. Clarendon Press. Oxford, England

Hewitt EJ (1966) The composition of the nutrient solution. In: Hewitt EJ (ed) Sand and water culture methods used in the study of plant nutrition: 187-246. Commonwealth Agricultural Bureau, Farmhand, UK
Huante P, Ceccon E, Orozco-Segovia A, Sánchez-Coronado ME, Acosta I, Rincón E (2012) The role of arbuscular mycorrhizal fungi on the early stage restoration of seasonally dry tropical forest in Chamela, México. Revista Arvore 36:279-289

Husband R, Herre EA, Young JPW (2002) Temporal variation in arbuscular mycorrhizal communities colonizing seedlings in a tropical forest. FEMS Microbial Ecol 42:131-136

INVAM (2014) International Culture Collection of (Vesicular) Arbuscular Mycorrhizal Fungi. West Virginia University, Morgantown, West Virginia. URL: http://invam.wvu.edu/the-fungi/species-descriptions (accessed March26 Janos DP (1980a) Mycorrhizae influence tropical succession. Biotropica 12:56-64

Janos DP (1980b) Vesicular arbuscular mycorrhizae affect lowland tropical rain forest plant growth. Ecology 61:151-162

Janos DP (1996) Mycorrhizas, succession and the rehabilitation of deforested lands in the humid tropics. In: Frankland JC, Magan N, Gadd GM (ed) Fungi and Environmental Change: 129-162. Cambridge University Press, Cambridge, England

Kiers ET, Lovelock CE, Herre EA (2000) Differential effects of tropical arbuscular mycorrhizal fungal inocula on root colonization and tree seedling grow: implications for tropical forest diversity. Ecol Lett 3:106-113

Klironomos JN (2000) Host-specificity and functional diversity among arbuscular mycorrhizal fungi. In: Bell CR, Brylinsky M, Johnson-Green P (ed) Microbial Biosystems: New Frontiers: 845-851. Atlantic Canada Society for Microbial Ecology, Halifax, Canada

Kumar A, Singh S, Pandey A (2009) General microflora, arbuscular mycorrhizal colonization and occurrence of endophytes in the rhizosphere of two age groups of Ginkgo biloba L. of Indian Central Himalaya. Indian J. Microbiol 49:134-141

Lamb FB (1966) Mahogany of tropical America: Its ecology and management. University of Michigan Press, Ann Arbor, Ml

Le Tacon F, Garbaye J, Carr G (1987) The use of micorrhizas in temperature and tropical forest. Symbiosis 3:179-206

Lovelock CE, Ewel JJ (2005) Links between tree species, symbiotic fungal diversity and ecosystem functioning in simplified tropical ecosystems. New Phytol 167:219-228

Lovelock CE, Andersen K, Morton JM (2003) Host tree and environmental control on arbuscular mycorrhizal spore communities in tropical forests. Oecologia 135:268-279

Lovera M, Cuenca G (2007) Diversidad de hongos micorrízicos arbusculares (HMA) y potencial micorrízico del suelo de una sabana natural y una sabana perturbada de la gran sabana, Venezuela. Interciencia 32:108-114

Mayhew JE, Newton AC (1998) The Silviculture of Mahogany. CABI Publishing, Wallingford, UK

McGonigle TP, Miller MH, Evans DG, Fairchild GL, Swan JA (1990) A new method which gives an objective measure of colonization of roots by vesiculararbuscular mycorrhizal fungi. New Phytol 115:495-501

Mridha M, Dhar PP (2007) Biodiversity of arbuscular mycorrhizal colonization and spore population in different agroforestry trees and crop species growing in Dinajpur, Bangladesh. J For Res 18:91-96

Navarro C, Hernández G (2004) Progeny test analysis and population differentiation of Mesoamerican Mahogany (Swietenia macrophylla). Agronomía Costarric 28:37-51

Noldt G, Bauch J (2001) Colonization of fine roots of mahogany (Swietenia macrophylla King) by vesicular-arbuscular mycorrhizal fungi under plantation conditions in Central Amazon. J Appl Bot 75:168-172

OIMT (2004) Racionalizando el comercio de caoba. Informe del taller sobre el desarrollo de capacidad para la aplicación del listado de la caoba en el Apéndice II de la CITES. Organización Internacional de las Maderas Tropicales. Serie Técnica Núm 22, Pucalpa, Perú, p 56

Pérez-Rojas A, Torres-Orozco BR, Morales-Gutiérrez E, Pérez-Méndez E (2000) Textura, composición y contenido de materia orgánica de los sedimentos de un lago tropical de México. Hidrobiológica 10:41-50

Phillips JM, Hayman DS (1970) Improved procedures for clearing and staining parasitic and vesicular arbuscular mycorrhizal fungi for rapid assessment of infection. Transations Br Mycol Soc 55:158-161

Picone C (2000) Diversity and abundance of arbuscular mycorrhizal fungal spores in tropical forest and pasture. Biotropica 32:734-747

Pouyu-Rojas E, Siqueira JO, Donizetti JGS (2006) Symbiotic compatibility of arbuscular mycorrhizal fungi with tropical tree species. Revista Brasileira Ciência Solo 30:413-424

Ramírez-Gerardo M, Álvarez-Sánchez J, Guadarrama-Chávez P, Sánchez-Gallen I (1997) Estudio de hongos micorrizógenos arbusculares bajo arboles remanentes en un pastizal tropical. Bol Soc Bot Méx 61:15-20 
Ramos-Zapata J, Guadarrama P (2004) Los hongos micorrizógenos arbusculares en la restauración de comunidades tropicales. Universidad y Ciencia. No. especial I :59-65

Ramos-Zapata JA, Orellana R, Allen EB (2006) Mycorrhizal dynamics and dependence of Desmoncus orthacanthos Martius (Arecaceae), a native palm of the Yucatán península, México. Interciencia 31:364-370

Redecker D, Schüßler A, Stockinger H, Stürmer SL, Morton JB, Walker C (2013) An evidence-based consensus for the classification of arbucular mycorrhizal fungi (Glomeromycota). Mycorrhiza 23:515-531

SAS Institute Inc (2009) SAS/STAT user's guide. SAS, Cary, NC, USA

Schenck NC, Pérez Y (1990) Manual for the Identification of VA Mycorrhizal Fungi. Synergistic Publications, Gainesville, Florida, USA

Shi ZY, Chen YL, Feng G, Liu RJ, Christie P, Li XL (2006) Arbuscular mycorrhizal fungi associated with the Meliaceae on Hainan island, China. Mycorrhiza 16:81-87

Smith SE, Read DJ (2008) Mycorrhizal Symbiosis, 3rd edition. Academic Press, Cambridge, UK

Snook L (1996) Catastrophic disturbance, logging and the ecology of (Swietenia macrophylla King): grounds for listing a major tropical timber species in CITES. Bot J Linn Soc 122:35-46

Soto M, Gama L (1997) Climas. In: González-Soriano E, Dirzo R, Vögt R (ed) Historia Natural de Los Tuxtlas:7-23. Universidad Nacional Autónoma de México-CONABIO, México, D. F

Stürmer SL (2004) Effect of different fungal isolates from the same mycorrhizal community on plant growth and phosphorus uptake in soybean and red clover. Revista Brasileira Ciência Solo 28:611-622

Vandenkoornhuyse P, Baldauf SL, Leyva C, Straczek J, Peter WYJ (2002) Extensive fungal diversity in plants roots. Science 295:2051

van der Heijden MGA, Klironomos JN, Ursic M, Moutoglis P, Streitwolf-Engel R, Boller T, Wiemken A, Sanders IR (1998) Mycorrhizal fungal diversity determines plant biodiversity, ecosystem variability and productivity. Nature 396:69-72

Varela L, Trejo D (2001) Los hongos micorrizógenos arbusculares como componentes de la biodiversidad del suelo en México. Acta Zoológica Mexicana 1:39-51

Varela-Fregoso L, Estrada-Torres A, Álvarez-Sánchez FJ, Sánchez-Guillén I (2008) Catálogo ilustrado de hongos micorrizógenos arbusculares de la Reserva de la Biósfera de los Tuxtlas (versión electrónica en CD). Universidad Nacional Autónoma de México. México, D.F

Vargas R, Hasselquist N, Allen EB, Allen MF (2010) Effects of a hurricane disturbance on aboveground forest structure, arbuscular mycorrhizae and belowground carbon in a restored tropical forest. Ecosystems 13:118-128

Violi HA, Barrientos-Priego AF, Wright SF, Escamilla-Prado E, Morton JB, Menge JA, Lovatt CJ (2008) Disturbance changes arbuscular mycorrhizal fungal phenology and soil glomalin concentrations but not fungal spore composition in montane rainforests in Veracruz and Chiapas, Mexico. For Ecol Manag 254:276-290

Wubet T, Kottke I, Teketay D, Oberwinkler F (2009) Arbuscular mycorrhizal fungal community structures differ between co-occurring tree species of dry Afromontane tropical forest, and their seedlings exhibit potential to trap isolates suited for reforestation. Mycol Prog 8:317-328

Zangaro W, Bononi VLR, Trufen SB (2000) Mycorrhizal dependency, inoculum potential and habitat preference of native woody species in South Brazil. J Trop Ecol 16:603-622

\section{Submit your manuscript to a SpringerOpen ${ }^{\circ}$ journal and benefit from:}

- Convenient online submission

- Rigorous peer review

- Immediate publication on acceptance

- Open access: articles freely available online

- High visibility within the field

- Retaining the copyright to your article

Submit your next manuscript at $\gg$ springeropen.com 